\title{
DUYGUSAL EMEK: ÖNCÜLLERİ VE ARDILLARI
}

\section{Bilal EZILMEZ*}

\section{$\ddot{\mathbf{O} z}$}

$\mathrm{Bu}$ çalışmanın amacı duygusal emek konulu akademik çalışmalarda hangi öncüllerin ve sonuçların daha çok çalışıldığını tespit etmektir. Bu amaçla Türkiye'de Yüksek Öğrenim Kurulu tez veri tabanı ve duygusal emek kavramının en yakın ilişkilendirildiği örgütsel Davranış Kongresi bildirileri öncül ve sonuç değişkenleri açısından incelenmiştir. Ortaya çıkan sonuçlar tartışılmış ve genel olarak duygusal emek stratejileri ile çalışanların demografik değişkenleri, temel değerleri, duygu yönetimi, duygu düzenlemesi gibi duygularla ilişkili değişkenlerin öne çıktığı görülmüştür. Ayrıca akademik tezlere bakıldığında son on yıl içinde duygusal emek hakkında hazırlanan tez sayılarında önemli oranda artış olmasına karşın bu artış oranının örgütsel davranış kongrelerindeki çalışmalara yansımadığı tespit edilmiştir.

Anahtar kelimeler: Duygusal emek, Duygusal emek öncülleri, Duygusal emek sonuçları. Jel kodu: M12, M19

\section{Emotional Labor: The Antecedents and Consequences}

\begin{abstract}
The aim of this study was to determine which antecedents and results were studied in academic studies emotional labor. For this purpose, the Higher Education Board database and the studies of Organizational Behavior Congress which is associated with the concept of emotional labor in Turkey were examined in terms of the antecedent and consequences variables. The results are discussed and it is seen that the variables related to the emotions such as
\end{abstract}

* Dr. Öğr. Gör., Bandırma Onyedi Eylül Üniversitesi, bezilmez@bandirma.edu.tr 
demographic variables, basic values, emotion management, and emotion regulation have come to the fore with emotional labor strategies in general. In addition, it is determined that the number of thesis on emotional labor has increased significantly in the last ten years, but this rate of increase is not reflected in the studies in organizational behavior congresses.

Keywords: Emotional labor, Emotional labor antecedents, Emotional labor consequences. Jel code: M12, M19

\section{Giriş}

Son zamanlardaki araştırmalar, duyguların kurumlarda yoğunlaştığını ve iş hayatının kaçınılmaz bir parçası olarak kabul edilmeye başladı̆̆ını göstermiştir (Eroğlu, 2010). Duygu, bizi insan yapan niteliklerden biridir ve bunu da izlenim yönetimi için kullanırız. Evde veya iş yerinde başka insanlarla karşılaştığımızda kendine özgü bir tür sunmak için jestlerimiz, taklitlerimiz, kıyafetlerimiz, saçlarımız vb. duygularımızı kullanıyoruz ve yönetiyoruz. Denilebilir ki aslında insanlar örgütlerde ve iş yerlerinde birer duygu işçisidirler. Duygusal emek, duygu yönetimi ve duyguların düzenlenmesi gibi kavramlar bu nedenle günümüzde özellikle işletme biliminde ve onun bir alt alanı olan örgütsel davranış çalışmalarında sıkça kullanılır olmuşlardir.

Duyguların düzenlenmesi veya duyguların yönetilmesi motivasyon, hedefe yönelik davranış ve izlenim yönetimi gibi iş sonuçları açısından da için kritik öneme sahiptir. Birtakım duyguların ifade edilmeleri ve bazılarının ise bastırılması, çalışanların kişisel kaynaklarını bir ölçüde tüketir ve müşteri ile temas eden çalışanlar için olumsuz sonuçlara da yol açar.

“Duygu yönetimi”, kişinin kendi duygularını ve ifadelerini değiştirme sürecini ve kişinin kendi davranışları üzerinde sahip olduğu özgürlüğün veya seçimin derecesini tanımlamak için "kişisel kontrol” ü ifade eder. Duygusal ifadelerin düzenlenmesi, iş bulma, sosyal destek alma ve daha yüksek performans dereceleri ve ipuçları gibi araçsal hedeflere katkıda bulunduğu görülmüştür. İş yerinde duyguları düzenlemek, araçsal ve kişilerarası hedefleri karşılamak için önemlidir (Kanfer ve 
Kantrowitz, 2002). Müşteri ile temas halinde olan çalışanlar için, bu hedefler müşteri memnuniyeti ve sadakatin ortaya çıkmasını sağlar (Pugh, 2001; Tsai, 2001).

Duygular konusunun işletme alanı açısından önemli bir boyutu da duygusal emektir. Duygusal emek, duyguların düzenlenmesi, duyguların ifadesi gibi konularla da yakından ilişkili bir kavramdır. Fiziksel ve zihinsel emeğin yanı sıra duygusal emeğin de alan yazında dikkate alınmaya başlanması, özellikle hizmet sektöründe yapılan araştırmalar ile artmıştır. Duygusal emek, bireyin diğer insanlarda belirli bir izlenim yaratmak için kendi duygularını yönetmesidir (Seçer, 2005). Duygusal emek konusundaki birçok çalışma, çalışanların duygusal ifadelerini değiştirdiklerini, stres, tükenmişlik ve iş memnuniyetsizliği yaşadıklarını göstermektedir. Müşterilerle ilişkilere odaklı duygu düzenlemesine sıklıkla katılan ve düşük iş özerkliğine sahip olan çalışanlar daha çok tükenmişlik göstermektedirler (Hochschild, 1983, Grandey, 2000). Sürecin olumlu sonuçları da söz konusudur. Çalışanların iş davranışları üzerinde daha fazla özerklik hissetmelerine izin vermek, duygularını daha olumlu yönetebilecekleri için kendilerini kişisel kaynaklarının daha etkin kullanımını sağlar (Hocshchild, 1979; Grandey, 2015).

Çalışanın duygularını yönetmesi için ise kullanabileceği iki temel strateji tanımlanmıştır. Bunlardan ilki yüzeysel rol yapmadır. Bu strateji kapsamında, çalışan birey bir duyguyu hissediyor gibi rol yapmaktadır. İkinci strateji ise derinden rol yapma olup, bir duyguyu gerçekten hissetmeye çalışmaktır. Yüzeysel rol yapma yani aslında hissetmediği bir duyguyu sergileme, bireyin iç denge durumunda kalmasına engel olduğundan, çalışanlar ve örgüt açısından zararlı sonuçlara yol açabilmektedir. Duygusal emek bu bakımdan önem taşımakta olup, duyguların hissedilmesi ve sergilenmesi bağlamında örgütsel alana önemli bilgiler sunmaktadır.

$\mathrm{Bu}$ çalışmada duygusal emek üzerine gerçekleştirilen lisans üstü tezlerindeki öncüllerin ve sonuçların tespit edilmesi amaçlanmıştır. Bu çerçevede Türkiye'de Yüksek Öğrenim Kurulu tez veri tabanı ve duygusal emek kavramının en yakın ilişkilendirildiği Örgütsel Davranış Kongresi bildirileri değişkenleri açısından incelenmiştir. Böylece duygusal emek çalışacak olan araştırmacılara yön ve fikir verecek 
bir çerçeve ortaya konulacaktır. Duygusal emek üzerine daha önce çalışma gerçekleştirmiş ve bu çalışmaları geliştirmek isteyen veya bundan sonra lisans üstü tezi araştırması hazırlamayı planlayan bilim insanlarına seçecekleri bağımlı ve bağımsız değişkenler ile ölçekler hakkında da derli toplu bir bilgi sunulacaktır.

\section{Kavramsal Çerçeve}

Duygusal Emek kavramı ilk kez Hochschild tarafindan "Yönetilen Kalp: İnsan Duygularının Ticarileştirilmesi” (1983) adlı çalışmasında tanıtıldı ve "Duygusal Emek" giderek daha popüler hale geldi. Hochschild (1983), duygusal davranışı yüzeysel rol davranışı ve derin rol davranışı olmak üzere iki farklı boyutta açıklar. Genellikle derin rol davranışı olarak resmedilen duygusal emek, sıklıkla metodolojik davranış olarak da adlandırılır (Ashfort ve Humphrey, 1993). Duygusal Emek, sosyal normları sağlamak için duyguların kontrolünü ifade eder. $\mathrm{Bu}$, sosyal ve iş yaşamında gereklidir, bu yüzden çevresel koşulları ve bu sosyal normların nasıl sağlanacağını bilmek gereklidir (Öz, 2007). Ashfort ve Humphrey'e (1993) göre, duygusal emek hizmeti sağlayıcısı hizmet sunumu sırasında beklenen duyguları göstermektir. Takip eden araştırmacılar, Hochschild'in yaklaşımı olan yüzeysel rol yapma ve derinlemesine rol yapma davranışına - ki bunlar duygusal emek gösteriminin temel stratejileridir- üçüncü bir duygusal emek gösterme stratejisi olarak doğal duygusal emek gösterim davranışını (stratejisi) davranış hareketi eklemişlerdir (Ashfort ve Humphrey, 1993). Morris ve Feldman (1996), duygusal emek yapısını dört boyutta kavramsallaştırır: Doğru duygusal gösterimin sıklığı, istenilen gösterim kurallarına dikkat, gösterilecek duyguların çeşitliliği ve ortaya çıkması sonucunda ortaya çıkan duygusal uyumsuzluk ve gerçekte hissedilmeyen duygular.

\subsection{Duygu Kavramı ve Duygu Yönetimi}

Duygusal emek bir duygu yönetim ve düzenleme süreci olarak ele alındığ 1 için (Hochschild, 1983; Kart, 2011) insan davranışını belirleyen en önemli öğelerden olan duyguların bireyler tarafından iş yaşamlarında ve iş dışında kalan yaşamlarında 
çok farklı ve çeşitli olarak yaşandığı bir gerçektir (Erkuş ve Günlü, 2008). Bir gerçeklik olarak duyguların düzenlenmesi ve yönetilmesi iş yaşamında son derece önemlidir (Isenbarger ve Zembylas, 2006) ve performans belirlemede oldukça öne çıkmaktadır (Çukur, 2009). Bu nedenle duygusal emek kavramın ele alırken duygu ve duyguların yönetilmesi kavramlarına yakından bakmakta yarar olacağı açıktır.

Bir tanıma göre duygu, "belirli bir uyaran karşısında genellikle içsel olarak belirip, davranışsal bir tepkime olarak ortaya çıkan hisler"dir (Kervancı, 2008). Diğer bir araştırmacı ise duyguyu bir his ve bu hisse özgü düşünceler, psikolojik ve biyolojik durumlar ve bir dizi hareket eğilimi olarak tanımlamıştır (Goleman, 2007). Duygunun tanımlaması beraberinde farklı duyguların ve hatta duygu ile ilgili diğer bazı kavramları da gündeme getirecektir. Duygular, duygulanım ve duygu durumlar bunlardan başlıcalarıdır. İnsanların yaşadığı duygulara genel olarak "duygulanım" (his) adı verilmektedir (Barsade ve Gibson, 2007). Duygular ise doğrudan birine veya birşeye yönlendirdiğimiz güçlü hislerdir (Fridja, 1993). Duygu durum ise her zaman olmasa bile sıklıkla içinde bulunduğumuz durumdan bağımsız olarak yaşadığımız ruh hallerimizdir ve duyguları daha güçlü kılarlar (Weiss ve Cropanzano, 1996). Görüldüğ̈̈ gibi his ve ruh halleri gibi kavramlar da ister istemez konunun içinde yer almaktadırlar.

Deniz, Arslan, Özyeşil ve İzmirli’ye göre (2012) temel duygu durumları genel olarak olumlu ve olumsuz duygulanım olarak iki grupta incelenir. Yaşanılan duruma bağlı bir dürtüyle ilintili olmayan ve duygulardan daha az güçlü olan hisler olarak ta tarif edilen duygu durumlara heyecan, kendine güven ve neşe gibi olumlu örnekler verilirken; endişe, stres ve sinirlilik gibi olumsuz örnekler de gösterilebilir.

Duygular hem insanın durumunu ve kültürel kategorisini eşzamanlı bir şekilde gösteren bir araçtır (Barbalet, 1998) ve bu nedenle de duygular kişinin çevresinden ayrı düşünülemeyerek, farklı kültürel kategorilerde şekillenmiş hislerin kelimelere dökülmesini ve bunların duyguya dönüşmesini sağlayan araçlar olarak da dikkate alınmalıdır (Massumi, 2002). 
Duygular sadece kişisel ya da sosyal değil aksine "kişisel" ve "sosyal" kavramlarının tasvirinin yüzeylerini ve sınırlamalarını oluşturmaktadır (Ahmed, 2004). Bir başka deyişle, sosyalleşmesini tamamlamış bir toplumda yaşam, izole bir şekilde yaşayan canlıların aksine, insanların anlam ya da his tepkimelerini içeren ve bizim de bunu "duygu" altında incelediğimiz tepkime vermesini sağlar (Leavitt, 1996) ve buna göre duygu sadece biyolojiye indirgenebilecek ve basitçe sebep ve sonuçları ölçülebilecek bir kavram olmayıp, ancak bütün sosyal ve fizyolojik boyutların sürekli dikkate alımıla incelenebilir (Leavitt, 1996).

Başka bir araştırmacının ifade ettiği gibi (Goleman, 2007) duygusal yeterlilikler kazanılan kabiliyetlerdir. Bu yeterliliklerin erken yaştan yetişkinliğe kadar olan süreçte aile, komşular, akranlar, dinler ve sosyal gruplar tarafindan etkilenerek oluşması durumu söz konusudur ve bu sebeple yeterliliklerden oluşan duygusal sermayenin eğitimle kazanıldığ 1 ama bunun sadece okul eğitimiyle sınırlandırılamayacağı söylenebilir.

Duygular ve işgörenlere yansıyan sonuçlarının yöneticiler için önemli olduğu vurgulanan bir çalışmada (Ashkanasy ve Daus, 2001) örgütsel ortamlarda duyguların incelenmesinin, kuruluştaki insanların davranış biçimine yeni ve önemli bilgiler sağladığı sonucuna varılmış ve yöneticilere, organizasyonlarında olumlu bir duygusal iklim geliştirebilmelerini ve onlara yardımcı olabilmelerini sağlamak için öneriler sunulmuştur. Yöneticiler bireysel ve kurumsal bazda duyguları fark edecek donanımda olmalıdırlar.

İşgörenler, duygu yönetimini üç farklı rol ile duygu davranış kurallarına uyarak göstermektedirler: yüzeysel, derinlemesine ve doğal (Morris ve Feldman, 1996). Yüzeysel rol davranışı, gerçekte hissedilmeyen duyguların yüz ifadeleri ve mimiklerle ya da farklı ses tonuyla hissediliyormuşçasına sunulmasıdır (Hochschild, 1983). Duygusal Emek sergilemenin birinci yolu olan yüzeysel rol davranışı, işgörenin hiçbir duygu yaşamadığı ve hissetmediği anlamına gelmemektedir. Yalnızca burada gösterimi yapılan duygu ifadesinin hissedilen duygudan farklı olduğu vurgulanmaktadır. Duygusal gösterim kurallarına uyum sağlamak için kullanılan 
ikinci yol ise derinlemesine rol davranıştır. Derinlemesine duygusal emek (rol) davranışında işgören tarafından sergilemek istenilen duygunun gerçekten hissedilme çabası söz konusudur (Hochschild, 1983). Yüzeysel duygu davranış1 işgörenin dolaysız, yani doğrudan gözlemlenebilen duygu davranışına odaklanırken; derinlemesine duygusal davranış işgörenin daha çok iç dünyasında hissettiği duygulara vurgu yapar (Morris ve Feldman, 1996). Öte yandan, bazı durumlarda işgörenlerin herhangi bir duygusal emek düzenlemesine ihtiyaç hissetmeden, samimi ve doğal olarak kendilerinden beklenen duyguları sergileyebilecekleri ifade edilmektedir (Wouters, 1989; Ashforth ve Humprey, 1993; Morris ve Feldman, 1996). Bu durumda işgörenden beklenen duygunun sergilenmesinde doğal duygusal emek gösterimi üçüncü bir yol olarak görülmekte ve işgörenlerin gerçekten yaşayıp hissettiği için iş gereği duygularını ifade edebilecekleri belirtilmektedir.

İnsanların sosyal hayatlarında duygularını kontrol etmeleri ile birlikte duygusal emek başlamıştır denilebilir (Hochschild, 1983). Örgütsel araştırmalar ve yönetim içinde duygu, arzulanan duygular, duygu işi ve duygusal emek olarak kendine yer bulur. Duygusal emekçilerin kimlikleri, işgören performansları ve duyguyu metalaştırmaları özellikle ele alınan konulardır. Bu bağlamda hizmet sektörünün gelişmesi ile duygusal emek olgusunun rekabet açısından ve hizmet sağlayanlar açısından kavram olarak vazgeçilmez bir konuma geldiği görülmektedir (Hochschild, 1983).

\subsection{Alanyazın Taraması}

İş ortamında örgüt kültürünün bir gereği olarak uygun duygular sergilemek için gerçek duyguların düzenlenmesi ve gösterilmesi olarak ifade edilebilen duygusal emek kavramı, örgütsel başarı için çok önemlidir (Isenbarger ve Zembylas, 2006). Günümüz iş dünyasında, duyguları duygusal talebe göre düzenlemede ve yönetmede çalışanların sahip oldukları çabalar ve deneyimler, aynı zamanda duygusal emek olarak adlandırılır ve kuruluşların performanslarını belirlemede ön plandadırlar (Çukur, 2009). Bu nedenle kuruluşların çalışanlarının, en değerli varlıklarının duygularını anlamaları ve ruh hallerini organizasyonun başarısına katkıda bulunacak şekilde etkilemesi gerekir. 
Eğitim, sağlık, hizmet ve finans sektörünün vazgeçilmez bir parçası olan duygusal emek, farklı yaş gruplarındaki hastaların sağlığı ile duygusal ve bilişsel reaksiyonları etkileyen sağlık sektörü işgörenleri açısından da özel bir öneme sahiptir (Hochschild, 1983; Wharton, 1999; Sutton ve Wheatley, 2003).

Duygusal emek davranış kuralları işgörenlere ne kadar belirgin ve net olarak gösterilir ve öğretilirse duygusal davranış gösterim kuralları o kadar açık demektir. işgörenlerin duyguları üzerinde ne denli kontrolde bulunmak istiyorlarsa örgütün o oranda davranış kurallarını açıkça işgörenlerine aktarmaya çalışması gerekmektedir (Hochschild, 1983; Şengül, 2009).

Hochschild (1983) yaş ilerledikçe işgörenlerin gösterilmesi gereken duyguları daha çok kolaylıkla gösterebileceklerini ifade etmektedir. Cinsiyet açısından da kadınların daha çok duygusal emek gösterimi ortaya koymada erkeklerden önde olduklar1 genel olarak belirtilmektedir. (Hochschild, 1983; Rafaelli ve Sutton, 1989; Morris ve Feldman. 1996; Köksel, 2009). Yapılan bazı çalışmalarda işgörenin evli olup olmaması duygusal emek gösterim düzeylerinde farklılık ortaya koymuş (Eroğlu, 2009) fakat diğer bazı çalışmalarda ise medeni durumun duygusal emek gösteriminde herhangi bir etkisinin olmadığı saptanmıştır (Oral ve Köse, 2011). İşgörenin duyguları ve buna bağlı davranışları hem çalıştığı sektöre göre hem de iş yeri ve iş yaşamındaki tecrübesine göre farklılık gösterebilmektedir (Kaya ve Özhan, 2012).

Kadınlar veya duygusal olarak daha iyi durumda ifadelerini ortaya koyabilenler ön saflarda müşterilerle ilgilenebilirler. Hem cinsiyet hem de farklı sosyo-kültürlerden gelenlerde farklı duygusal emek gösterim davranış sonuçları çıkabileceğine dair alanyazında çalışmalar mevcuttur (Hochschild, 1983).

Duyguları açısından olayı yaşayan ve müşteriler ile daha uzun sürelerde meşgul olan işgören duygularını yönetmektedir. Böylece duygu yönetimi ve duygusal emek gösterimi bir içiçelik durumu da gösterir. Duygusal emek işletme için iyi sonuçlar verebilir fakat işgörenin sağlığına dönük olumsuz sonuçları da olabilecektir. Derin rol davranış yüzeysel rol davranışa göre daha olumlu hizmet ortaya çıkarsa 
da her ikisi de tükenmişlik, çözülme ve olumsuz iş tutumlarını sonuç verebilmektedir (Grandey, 2000; Brotheridge ve Lee, 2003; Seçer, 2005). Bu yaklaşımda derinlemesine ve yüzeysel rol içeren duygusal emek davranışları ayrı ayrı incelenmekte ve duygusal düzenleme kavramı da duygusal emek araştırmasına dahil edilerek çalışma ortamında kişinin bir uyaranla karşılaştığında duygularını kontrol ederek duygusal dengesini sağlaması ve duruma uygun tepkiyi vermesi öngörülmektedir.

Duygularını engelleyebilenlere nazaran durumları yeniden değerlendirerek duygu durumlarını değiştirebilen işgörenler hizmet sunumu içeren meslekler için daha uygun olabilecektir. Yüzeysel rol davranışı ve derin rol davranışının çevre ile etkileşimlerinin incelenmesi gerekliliği de bu çalışmada vurgulanan diğer bir husustur (Diefendorff vd., 2005). Yüzeysel rol davranışının duygusal tükenmişliğe yol açtığı sonucuna ulaşan çalışmalar vardır (Hochschild, 1983; Kruml ve Geddes, 2000; Brotheridge ve Lee, 2003) fakat bazı çalışmalarda duygusal emek gösterim stratejileri ile duygusal tükenmişlik arasında ilişki bulmayan, hatta çelişkili sonuçlar bulunduğunu belirten çalışmalar da mevcuttur (Kruml ve Geddes, 2000; Brotheridge ve Grandey 2002; Chu, 2002; Brotheridge ve Lee, 2003; Chu ve Murrman, 2006).

Güngör Delen (2009) ise çalışmasında duygusal emek konusunu teorik olarak bütün boyutları ile incelemeye çalışmıştır. İş yaşamında yaygınlaşan ve özellikle müşteri ile yüz yüze ilişkiyi zorunlu kılan hizmet sektöründeki işlerde kendisini gösteren duygusal emek yaklaşımı, toplumun hizmet çalışanlarından güler yüzlü bir nezaket ve hizmet kalitesi beklediğini ileri sürmektedir. Duygusal emek kavramının, hizmet sektöründe özellikle müşterilerle bire bir ilişkide bulunan işgörenin emek ortaya koyması sürecinde kullanılan bir kavram olduğu ifade edilmektedir. Çalışanların düşünsel emeklerinin yanı sıra, duygularını da emek sürecine dâhil etmek zorunda kalmaları ile bu süreç yaşanmaktadır. Duyguların bir emek türü olarak kullanılması ise işgörenin ortaya koyabileceği son gücü olduğunu belirtenler olmuştur. Böylece işgörenin duyguları da piyasanın sağlıklı işlemesinin birer aracı haline gelmiş ve özel alandan tüketim alanına intikal ederek üretim ve satış sürecine dâhil olmuş bulunmaktadır (Güngör Delen, 2009). 
Duygu düzenlemesi kavramı duyguların ve ifadelerin düzenlenmesinde yeniden değerlendirmeyi ve gerektiğinde bazı duyguları baskılamayı kullanırken duygusal emek derin duygusal emek rol davranışını ve yüzeysel duygusal emek rol davranışlarını kullanmaktadır. Bireysel ve toplumsal çıktılar açısından duygu düzenlemesi ve duygusal emek kavramları karşılaştırıldığında ise ruh halleri ve baskı bireysel, ilişkisel algılamalar ise toplumsal olarak duygu düzenleme süreçlerinin çıktılarıdır. Duygusal emek sonuçları olarak ise tükenmişlik ve iş tatmini ile performans derecelendirmeleri söz konusu olmaktadır (Grandey, 2015).

Grandey ve Gabriel (2015), duygusal emek çalışmalarının geleceğinin sağlıklı gelişimi açısından sonuçların ve aracı değişkenlerin hem mesleki hem de örgütsel refah açısından birlikte değerlendirilmesi gerektiğini vurgulamaktadır. Duygusal emek ve etkenleri arasındaki ilişkileri sınayıp test edecek deneysel ve alan çalışmalarına gereksinim olduğu görülmektedir (Grandey vd., 2015).

Grandey, Rupp ve Brice'a göre (2015) duygusal emeğin gülümseme olarak hizmet etmesinin insani maliyetine dikkat çeken bir çalışmada, çalışanlardan önce olumlu duyguları sergileme zorunluluğu, hizmet sunumunu tehdit eden uygulamaları da değerlendirilmektedir. Duygusal uyumsuzluk ve kaynak eksikliğine odaklanmak için bir çağrıdır bu aynı zamanda. Bunun nedeni, duygu kurallarının oluşturulmasının işgörenin özgür iradesini sınırladığı, özerkliği, yetkinliği ve aidiyeti tehdit ettiği gibi görülen durumlardır.

Alanyazındaki bir son dönem araştırmasında (Chi ve Grandey, 2016) yeni bir modelde duygusal emek (DE) için önemli bir husus olan duygu istikrarı ele al1narak bunun olumlu ve olumsuz ruh halleri ile etkileşimlerinin hizmet sunumuna etkilerini araştırılmaktadır. Buna göre derinlemesine DE rol davranışı bazı kişilik özellikleri ile pozitif ilişkilidir ve bu durumda istenen etkin hizmet sunumu gerçekleşebilmektedir.

Bu modelin diğer bir varsayımı da aktif kişilik özelliklerden daha düşük motivasyonel eğilimlere yani, (dışa dönüklük, açıklık ve kabul edilebilirlik) sahip kişiler tarafından derin DE rol davranışı gösterilmesi istenen hizmetin etkin sunumu ile 
daha fazla ilişkilidir. Yine yüzeysel DE rol davranışı kişilik özellikleri açısından yüksek engelleme odaklı motivasyon eğilimleri olan dikkatli ve duygusal istikrarlı kişiler tarafından kullanıldığında, sunulan hizmetin sekteye uğraması daha az söz konusu olmaktadır (Chi ve Grandey, 2016).

Duygusal emek kavramının bütün boyutları ile tartışılması ve duygusal emek çalı̧̧malarının geleceğinin sağlıklı gelişebilmesi açısından öncüller, sonuçlar ve aracı değişkenlerin hem işgören hem de örgüt iyiliği için birlikte ele alınması gerektiğine vurgu yapılmaktadır. Yap1 ve ölçüm karmaşıklı̆̆ı öncüllere dönük anlayış sınırlılığı gibi etkenlerin sağlıklı ve iyi sonuçlar için test edilmesi gerekliliğini de öneri olarak dile getirmektedirler (Grandey ve Gabriel, 2015).

Duygular aslında özel alana ait unsurlar iken işgörenlerin örgüte bağlllıklarını daha güçlü kılmak ve bu şekilde daha fazla katma değer üretmeleri ve daha etkin hizmet sunabilmeleri için işyerlerine de taşınmıştır (Güngör-Delen, 2017). Çalışanın duygularını derinden etkileyen inanç, maneviyat ve dindarlık gibi kavramlar da yine benzer gerekçelerle iş yaşamına taşınarak örgütsel davranış alanında ele alınmaya başlamışlardır (Ezilmez ve Eroğlu, 2017; Güngör-Delen, 2017; Ezilmez, 2018).

Duygusal emeğin yapısı örnek alınarak oluşturulan manevi emek kavramı, örgüt üyelerinin maneviyatının metalaştırılması, kodlanması ve düzenlenmesi olarak tanımlanmakta ise de (McGuire, 2010) görece yeni bir kavram olduğu için üzerinde anlaşılmış net bir tanım veya ölçek henüz tam olarak oluşmamıştır (Güngör-Delen, 2017).

\section{Yöntem}

Bu çalışmanın amacı, tartışmasız bir şekilde çalışanlar ve örgütler açısından büyük öneme sahip olan duygusal emeğin, hangi değişkenler ile ilişkilendirildiğini ve bu ilişkilerin yönünü ortaya koymaktır. Bu amaçla nicel bir araştırma yöntemi olarak bibliyometri analizi ile incelenecek araştırmalar dizinde duygusal emek olan lisansüstü tezler ile sınırlandırılmış ve Yükseköğretim Kurulu (YÖK) ulusal tez mer- 
kezi veri tabanında yer alan izinli tezler "duygusal emek" konu başlığı ile gerçekleştirilen son 10 y1lın tezleri taranmıştır. Yapılan inceleme sonucunda alanda toplamda 75 (16 doktora, 59 Yüksek lisans) tezin hazırlanmış olduğu tespit edilmiştir.

Bu çalışmada Yüksek Öğretim Kurulunun (YÖK) ulusal tez merkezi veri tabanında yer alan lisan üstü tezleri kullanılan duygusal emek ölçekleri, araştırmanın değişkenleri ve sektörleri bakımından incelenmiştir. Bu çalışma ile duygusal emeğe ilişkin bir çerçevenin sunulması, eldeki sınırlı tezler ve kongre bildirileri dâhilinde öncel ve sonuçlarının tespit edilmesi hedeflenmiştir. Böylece alan yazında 1983 y1lından bu yana yer tutmuş olmasına karşın farklı ölçeklerin ve farklı alt boyutların çalışıldığı duygusal emek kavramında belki de belirsizliklerin ortadan kalkmasını sonuç verebilecek çalışmalar gerçekleştirilebilir. Daha önce çalışılmayan ve az çalışılan değişkenler ile duygusal emek kavramının ilişsisinin ortaya konulması da böylece mümkün olabilecektir. Bu nedenle çalışma, konuya ilgi duyan araştırmacılara bir özet ve rehber olmak bakımından katkı sağlayacaktır. Tablolarda yıllara göre tezler, kullanılan ölçekler, bağımlı ve bağımsız değişkenler ve araştırmanın yapıldığı sektörler yer almıştır. Çalışmada Örgütsel Davranış Kongrelerinde sunulan duygusal emek ile ilgili bildiriler de gözden geçirilmiştir.

\section{Bulgular}

Yüksek Öğrenim Kurumu Ulusal Tez Merkezi’nde dizin tarama penceresinde "duygusal emek" konusu ile yapılan arama sonucu 95 lisansüstü tez bulunmuştur. Bunlardan araştırmacıların incelemesine açık olan 75 tanesi incelenmiştir. Bu 75 lisans üstü tezinin 16 tanesi doktora tez araştırması olarak bitirilen çalışmalar iken diğer 59 adet çalışma ise yüksek lisans tezidir. Aşağıda tablo 1'de görüleceği gibi 2009 yılı ile 2018 yılının bitmesine bir ay kala dönem içerisinde gerçekleştirilen lisansüstü tez sayıları artış göstermiştir. İzinsiz olan tezlerin izinli duruma gelmeleri bu sonuçları her an değiştirebilecektir. Örneğin izinli-izinsiz tezlerin toplamı 95 olarak karşımıza çıkarken 2018 yılı Aralık ayının 15. günü itibariyle 75 tane izinli teze 
ulaşılabilmiştir. Bu sayılar bize duygusal emek kavramının gerçekleştirilen akademik tez alışmaları açısından da önem kazandığını ortaya koymaktadır. Özellikle 2012 ve 2015 yıllarında bu konudaki araştırmaların ivme kazanmış olduğu da ayrıca ifade edilebilir.

Tablo 1: Duygusal Emek Üzerine Gerçekleştirilen Lisansüstü Tezleri

\begin{tabular}{|c|c|c|c|}
\hline & $\begin{array}{c}\text { Tezin Kabul } \\
\text { Edildiği Y1l }\end{array}$ & $\begin{array}{c}\text { İzinli Tez } \\
\text { Sayı1 } 1\end{array}$ & $\begin{array}{c}\text { Toplam } \\
\text { Tez Sayıs } 1\end{array}$ \\
\hline 1 & 2009 & 1 & 1 \\
\hline 2 & 2010 & 3 & 3 \\
\hline 3 & 2011 & 2 & 2 \\
\hline 4 & 2012 & 6 & 6 \\
\hline 5 & 2013 & 5 & 5 \\
\hline 6 & 2014 & 14 & 14 \\
\hline 7 & 2015 & 13 & 13 \\
\hline 8 & 2016 & 14 & 17 \\
\hline 9 & 2017 & 9 & 21 \\
\hline 10 & 2018 & 9 & 11 \\
\hline & Toplam & 75 & 95 \\
\hline
\end{tabular}

Kaynak:https://tez.yok.gov.tr/UlusalTezMerkezi/tezSorguSonucYeni.jsp erişim: 15.12.2018

Ülkemizde son 10 y1l içinde gerçekleştirilen akademik lisansüstü tez çalışmalarında "duygusal emek" kavramı ile birlikte incelenen diğer değişkenlere bakıldığında ise sayıların ötesinde bu konuda yapılan tez araştırmalarının kapsamı hakkında bir fikir edinmek mümkün olabilecektir. Aşağıda yer alan çizelge 2'de gerçekleştirilen lisansüstü tez çalışmalarında sıklıkla kullanılan değişkenler öncüller ve sonuçlar olarak görülmektedir.

Tablo 2: Duygusal Emek Araştırmalarında Siklkkla Kullanılan Değişkenler

\begin{tabular}{|l|l|}
\hline \multicolumn{1}{|c|}{ Öncüller } & \multicolumn{1}{c|}{ Sonuçlar } \\
\hline$\bullet$ Kişilik & $\bullet$ İş tatmini \\
$\bullet$ Demografik & $\bullet$ (Duygusal) Tükenmişlik \\
$\bullet$ Toplumsal Konum & $\bullet$ Duygusal uyumsuzluk \\
\hline
\end{tabular}




\begin{tabular}{|c|c|}
\hline • İş Ünvanı & - Duygusal bulaşma \\
\hline - Ahlaki değerler & - İşgören refahı \\
\hline - Örgütsel Destek alg1sı & - Çalışan Performansı \\
\hline - Amir, ast ve Meslektaş desteği & - Çalışan iş bırakma \\
\hline - Etik liderlik & - Müşteri tatmini \\
\hline - Duygu durum & - İş bırakma niyeti \\
\hline - İletişim becerisi & - Duyuşsal (etkin) hizmet sunumu \\
\hline - Öğretmen davranışı & - Geri çekilme davranışı \\
\hline - Liderlik Modelleri & - Algilanan prestij \\
\hline - Güdüleme & • Örgütsel özdeşleşme \\
\hline - Olumlu duygulanım & - İş stresi \\
\hline - Dindarl1k & - Yabancilaşma \\
\hline - Motivasyon & - Duyarsızlaşma \\
\hline • Örgütsel kültür & • İş sonuçları \\
\hline - Duygusal Zekâ & - Hizmet kalitesi \\
\hline - Psikolojik sermaye & • İş-aile çatışması \\
\hline
\end{tabular}

Kaynak: https://tez.yok.gov.tr/UlusalTezMerkezi/tez_SorguSonucYeni.jsp erişim: 15.12.2018

Ulusal Tez Merkezinde izinli ve izinsiz olarak yer alan lisans-üstü ve doktora tez araştırmalarında sıkça kullanılan değişkenlerden ayrı olarak duygusal emek gösterim kuralları, duygusal emek gösterim sıklı̆̆ı, duygusal emek gösterim süresi ve gösterilen duygusal emek çeşitliliği gibi duygusal emek kavramının bir parçası gibi görülebilecek konular da sıklıkla öncül değişken olarak araştırma konusu olmuşlardir.

Araştırmalarda sıklıkla değişken olarak kullanılan öncüllere ve sonuçlara bakıldığında neredeyse örgütsel davranış çalışmalarındaki temel konuların bütünüyle ele alındığı görülmektedir. Özellikle bireylerin ve çalışanların duyguları ile yakından ilgili olabilecek konulara artık günümüzde işletme biliminin yönetim organizasyon ve örgütsel davranış alanı çalışmalarında kolaylıkla kendilerine yer bulmaktadır. Günümüzde artık çalışanların duygularının işverenler tarafından ihmal edilmesi telafisi mümkün olmayacak sonuçlara yol açabilmektedir. Örgütler sundukları hizmetin üst düzey olabilmesininrekabet edebilirlikaçısından kaçınılmaz olduğunu bilmektedirler. 
Denilebilir ki “duygusal emek" kavramı ile ilgili çalışmaların en sıkıntılı yanı araştırmalarda bu değişkeni ölçmek için alan yazında çok sayıda ölçek bulunuyor olmasıdır. Aşağıdaki bilgiler (Tablo 3) bu durumu doğrular mahiyettedir. Bu çalışma için gözden geçirilen seksene yakın tez araştırmasında da çok sayıda ölçek kullanılmıştır. İşletme biliminde ve sosyal bilimlerin birç̧ok alanında (örneğin Tükenmişlik gibi, Duygusal Zekâ gibi) belli bazı kavramlar için neredeyse standart olmuş bir veya birkaç ölçek ile o alanda genel kabul görmüş bazı ölçekler söz konusudur.

Tablo 3’te de görüldüğü gibi Yüksek Öğrenim Tez Merkezi’nde kayıtlı tezlerde yapılan taramada sık kullanılan "duygusal emek" ölçekleri bile başlı başına bir tablo oluşturabilmektedir. Elbette, “duygusal emek” kavramının turizmden eğitime, sağlıktan çağrı merkezlerin ve hatta güvenlik güçleri ve adalet teşkilatı çalışanlarına kadar geniş bir yelpazede araştırılması bu durumu bir ölçüde anlaşılır kılmaktadır. Yine de çok farklı "duygusal emek" ölçeği ve tercümelerde ortaya çıkan sıkıntılar bu alanda ölçeklere dönük olarak da çok çalışma yapılması gerektiğini bizlere söylemektedir.

Chu ve Murman (2006) tarafindan geliştirilen ölçek daha çok turizm çalışmalarında tercih edilmektedir. Grandey (1999)'in doktora tezinde kullandığ 1 ve sonrasında geliştirdiği ölçek de araştırmacılar tarafından sıklıkla tercih edilmekte ve duygusal emek çalışmalarına büyük faydaları olmaktadır. Basım ve Beğenirbaş (2012)'ın oluşturdukları ölçek de Türkiye'de önemli bir boşluğu doldurmaktadır. Çukur (2009)'un ölçeği ile birlikte düşünülürse, bu ölçekler araştırmacılar için önemli seçenek oluşturmaya başladıkları görülmektedir.

Tablo 3: Duygusal Emek Lisansüstü Tezlerde Kullanılan Ölçekler

\begin{tabular}{|c|l|c|}
\hline \multicolumn{1}{|c|}{ Ölçeğini Geliştiren Araştırmacı(lar) } & $\begin{array}{c}\text { Kullanıldı̆̆ı } \\
\text { Tez Sayısı }\end{array}$ \\
\hline 1 & Chu ve Murrmann (2006) & 16 \\
\hline 2 & Grandey (1999) & 12 \\
\hline 3 & Diefendorff vd. (2005) & 10 \\
\hline 4 & Basım ve Beğenirbaş (2012) & 10 \\
\hline
\end{tabular}




\begin{tabular}{|c|l|c|}
\hline 5 & Brotheridge ve Lee (1998) & 7 \\
\hline 6 & Kruml ve Geddess (2000) & 6 \\
\hline 7 & Çukur (2009) & 1 \\
\hline 8 & Hocshchild (1983) & 1 \\
\hline 9 & Öz (2007) & 1 \\
\hline 10 & Zapf vd. (1999) & 3 \\
\hline 11 & Yarı yapılandırılmış görüşme & 1 \\
\hline 12 & DE hakkında 1 Evet-Hayır sorusu & 1 \\
\hline 13 & Derinlemesine görüşme & 1 \\
\hline 14 & Ölçek Geliştirme + Yarı Yapılandırılmış Soru seti & 1 \\
\hline 15 & Katılımcı-gözlemci araştırması & 75 \\
\hline 16 & Ölçek kaynağı belirtilmemiş & 1 \\
\hline & Toplam & 1 \\
\hline
\end{tabular}

Kaynak: https://tez.yok.gov.tr/UlusalTezMerkezi/tezSorguSonucYeni.jsp, erişim: 15.12.2018

Duygusal emek araştırmalarında ölçeklerin tercih edilmesini belirleyen bir unsur da araştırmanın hangi sektörde yapılacağıdır. Hizmet iş kolunda olmak üzere duygusal emek birçok alanda geçerli bir olgudur. İşletmeler mal veya hizmetleri üretmekte veya ticaret işletmeleri olarak faaliyetlerini yürütmektedirler. İşgörenler duygularını kendilerine doğrudan hizmet sunumunda bulundukları müşterilere dönük olarak ortaya koydukları için hizmet sektörü duygu yoğun bir sektördür. Tablo 4'te araştırmada öne çıkan sektörler görülmektedir.

Turizm, sağlık ve eğitim sektörleri duygusal emek açısından neredeyse stratejik iş alanlarıdır. Bu alanlarda müşterilere pozitif duyguların gösterimine dair kurallar önceliklidir ve bu gösterimlerin derin duygusal emek veya doğal duygusal emek stratejileri ile gerçekleştirilmesi beklenmektedir (Hocshchild (1983). Güvenlik, finans, spor ve cenaze hizmetleri gibi çok değişik alanların duygusal emek kavramı için araştırmacıları beklediği söylenebilir. Özellikle güvenlik ve adalet gibi alanlarda çalışmalar negatif duyguları daha çok gösterme üzerine odaklanabilir; yine istenen etkiyi ortaya koyabilme açısından derin duygusal emek veya doğal duygusal 
emek stratejileri birlikte ele alınabilir (Grandey, 2000; Kruml ve Geddes, 2000; Chu ve Murman, 2006).

Tablo 4'te kesimlerine göre son on yllda gerçekleştirilen lisans üstü tez sayıları görülmektedir. Turizm, sağlık ve eğitim kesimleri en fazla duygusal emek çalışılan kesimler olarak öne çıkmaktadır. Bazı sektörlerde birden fazla meslek bir arada yer alabilmektedir. Örnek olarak; doktorlar, sağlik teknisyenleri ve hekimler gibi. Tablodaki iş kolları ve meslekler hizmet kesiminde oldukları için üretim-ticaret ve finans kesiminden farklı olarak duygusal emek yoğun özellik taşımaktadırlar.

Tablo 4: TEZ-YÖK'deki Duygusal Emek Çalışmalarının Sektörlere Göre Dă̆ılımı

\begin{tabular}{|l|l|l|}
\hline & Sektörler & Tez sayısi \\
\hline 1 & Turizm & 19 \\
\hline 2 & Sağlık & 16 \\
\hline 3 & Eğitim & 15 \\
\hline 4 & Kamu Kurumu-idari personel ve yerel yönetim çalışanları & 10 \\
\hline 5 & Diğer Hizmet (kuaför, çağrı merkezleri vs.) & 8 \\
\hline 6 & Finans-Bankacılar & 6 \\
\hline 7 & Uçak Kabin memurları & 3 \\
\hline 8 & Sivil Havacılık ve Antrenör-Sporcular & 2 \\
\hline 9 & Avukatlar & 2 \\
\hline 10 & Evde bakım hizmeti veren ev kadınları & 2 \\
\hline 11 & Reklamcılık & 1 \\
\hline 12 & Akademisyenler & 1 \\
\hline
\end{tabular}

Kaynak: https://tez.yok.gov.tr/UlusalTezMerkezi/tezSorguSonucYeni.jsp,erişim: 15.12.2018

İşletme biliminin gelişmesiyle birlikte muhasebe, üretim, yönetim ve organizasyon ile örgütsel davranış gibi yeni alanlar ortaya çıkmaya başlamıştır. Beraberinde uzmanlaşmayı da sonuç veren bu gelişmelerin sonucunda 2013 yılında ilk defa örgütsel davranış çalışmalarına özgü olmak üzere müstakil bir kongre düzenlenmiştir. İnsan duygularının iş dünyasına bakan yönünü ifade eden "duygusal emek" kavramı da elbette Örgütsel Davranış Kongresi'nin alanına giren bir konu olacaktı. Bu 
sebeple son beş yılın Örgütsel Davranış Kongre konuları da araştırmada gözden geçirilmiştir. Ne yazık ki akademik tezlerde belirgin bir şekilde artış gösteren "duygusal emek" araştırmaları bu kongrelerde henüz aynı ivmeyi yakalayamamıştır.

Çizelge 5: Örgütsel Davranış Kongrelerindeki (ÖDK) Duygusal Emek Çalışmaları Sayısı

\begin{tabular}{|c|c|c|c|}
\hline Kongre ve Yılı & $\begin{array}{c}\text { Çalışma } \\
\text { Sayısı } \\
\end{array}$ & Sektör & Araştırma Değişkenleri \\
\hline 1. ÖDK 2013 & 1 & Özel sektör & $\begin{array}{l}\text {-İş performansı } \\
\text {-İşen ayrılma niyeti } \\
\text {-Kişiler arası çarpıklık } \\
\text {-Negatif duygusallık } \\
\text {-Bağlamsal performans } \\
\text {-İş-sosyal destekleri }\end{array}$ \\
\hline 2. ÖDK 2014 & 5 & $\begin{array}{l}\text {-Sağlık } \\
\text {-Eğitim } \\
\text {-Satış } \\
\text {-Mağaza çalışanları } \\
\text {-Turizm }\end{array}$ & $\begin{array}{l}\text {-Psikolojik sermaye } \\
\text {-İşe yabancılaşma } \\
\text {-İşodaklı DE } \\
\text {-Duygusal Tükenmişlik } \\
\text {-Örgütsel bağlılık } \\
\text {-Örgütte kalma niyeti } \\
\text {-Mesleki bağll1lk } \\
\text {-İş tatmini } \\
\text {-Kişi-iş uyumu } \\
\text {-Toplumsal cinsiyet } \\
\text {-Duygu yönetimi }\end{array}$ \\
\hline 3.ÖDK 2015 & 6 & $\begin{array}{l}\text {-Eğitim } \\
\text {-Sağlık } \\
\text {-Hastane hostesleri } \\
\text {-Hasta ve yakınları }\end{array}$ & $\begin{array}{l}\text {-İş stresi } \\
\text {-Psikolojik sermaye } \\
\text {-Psikolojik sözleşme } \\
\text {-Mesleki özdeşleşme } \\
\text {-Performans } \\
\text {-Pro-sosyal motivasyon } \\
\text {-İşe gömülmüşlük } \\
\text {-Normlar }\end{array}$ \\
\hline 4.ÖDK 2016 & 1 & -Sağlık (112 acil) & - Ekip çalışması tutumları \\
\hline 5.ÖDK 2017 & 3 & $\begin{array}{l}\text {-Sağllk } \\
\text {-Avukatlar }\end{array}$ & $\begin{array}{l}\text {-Örgütsel Destek Algisı } \\
\text {-Duygusal tükenmişlik } \\
\text {-İşgören performansı } \\
\text {-Dindarlık } \\
\text {-İşperformansı } \\
\text {-İşe tutulma }\end{array}$ \\
\hline
\end{tabular}


Tablo 5'e göre “duygusal emek” konulu araştırmaların Örgütsel Davranış Kongrelerine katılan araştırmacılar tarafından yeterince önem verilmediğini söylemek mümkündür. Öte yandan lisans üstü tezlerinde en çok duygusal emek üzerinde çalışma yapılan sektörler ile kongredeki en çok duygusal emek çalışılan alanlar, sektörler aynı gibidir. Sağlık sektörü çalışanları, turizm sektörü çalışanları ve eğitim alanında emek ortaya koyan öğretmen ve yöneticiler dönük duygusal emek çalışmaları bu alanda bir mutabakatın adeta altın çizmektedir. Bu durum emek yoğun olan hizmet sektöründe duygulara dönük araştırmaların kaçınılmaz olduğunu açıkça ortaya koymaktadır. Günümüz dünyasında insan ve duygularına yeterince önem verilmemesinden kaynaklanan yakınmaların var olduğunu düşünürsek önümüzdeki yıllarda bu kongrelerde de araştırmacılar tarafından "duygusal emek" kavramına hak ettiği önemin verilebileceği düşünülebilir.

\section{Sonuç}

Kişinin yani işgörenin işini yaparken sergilediği davranışları ile karşı tarafa belirli bir duygusal mesajın iletilmesini sağlamak, günümüzde artık üstlenilen iş rolünün bir özelliği olmaktadır. Dolayısı ile iş rolünü belli bir “duygu ifadesi” takınarak yapma ve karşı tarafa bu duygu ifadesini yansıtma boyutunda ele alınan duygusal emek çalışmaları özellikle sağlık, turizm ve eğitim gibi hizmet yoğun sektörlerin vaz geçilmezi olmuştur.

Bu çalışmada öncelikle duygusal emek hakkında hazırlanmış olan akademik tezler ve ilgili kongre bildirileri gözden geçirilerek tezlerin öncülleri ve ardılları incelenmiştir. Ortaya çıkan bulguların ışığında duygusal emek kavramının gelecekteki gelişimi öngörülmeye çalışılmıştır. Böylece, bu çalışma, duygusal emek alanında çalı̧̧mak isteyen araştırmacılara yeni bakış açıları sunmayı da hedeflemiştir.

Lisansüstü tez çalışmalarında bu kavrama dönük yapılan araştırmaların gözle görülür şekilde artması da bu duruma olan gereksinimi göstermektedir. Duygusal emek ile birlikte araştırılan bağımlı ve bağımsız değişkenlerdeki çeşitlilik bu kavramın ilgili alan yazın açısından önemini kapsam bazında da ortaya koymaktadır. 
Yine de daha önce duygusal emek araştırmalarına konu olmamış yeni sektörler, değişkenler ve yöntemler denenmelidir. Örneğin, reklamcılar ve akademisyenler üzerinde lisans üstü düzeyinde bu konu derinlemesine çalışlabilir. Evde bakım hizmeti veren ve bu işi aldıkları sosyal yardımlar ile gerçekleştiren, belki de vasıfsız diyebileceğimiz, ev hanımı (ve beyleri) ile bu alandaki maaşlı çalışanları karşılaştıracak çalışmalara da ilginç sonuçlar verebilecektir.

İş kolları açısından sağlık, turizm, çağrı merkezi, uçuş kabin görevlileri ve eğitim dışına da duygusal emek kavramı ile yenilikler getirip getiremeyeceğine bakabilecek araştırmacılar beklenmektedir. Yöneticiler, bankacılar ve siyasetçilere dönük duygusal emek çalışmaları da yok denecek kadar azdır. Ayrıca, üretim sektöründe çalışanların duygusal emek kullanımları hiç mi söz konusu değildir örneğin?

Araştırmacıların duygusal emek araştırmaları açısından çözmek zorunda kalacakları önemli bir husus ve aynı zamanda çalışılacak bir niş alan olarak duygusal emek kavramını daha sağlıklı bir şekilde değerlendirecek genel kabul görmüş bir ölçek oluşturma çalışmaları olabilir. Elbette, bu alanda Basım ve Beğenirbaş'ın (2012) geliştirdikleri ölçeğin önemi görmekten gelinemez.

Ayrıca, duygu düzenlemesi ve yönetimi ile duygusal emek kavramının birleştikleri ve ayrıldıkları noktaları açıklığa kavuşturacak çalışmalara da ihtiyaç olduğu vurgulanmalıdır. İnsan ve duygularını en çok etkileyen inanç, maneviyat ve dindarlık kavramları da duygusal emek açısından neredeyse hiç ele alınmayan konular olarak göze çarpmaktadır. Kongrelerde ve ikili görüşmelerde konuyu araştıran akademisyenlerin önemle vurguladıkları bir diğer konu da artık bu kavramın deneysel çalışmalarla da desteklenerek daha fazla anlaşılır kılınmasının sağlanmasıdır.

$\mathrm{Bu}$ çalışmanın bulgularından hareketle daha önce duygusal emek ile birlikte ele alındığında olumlu sonuçlar veren öncüllerin çalışılmasına ve daha önce çalışılmamış fakat olumlu sonuç verebileceği tahmin edilebilen değişkenler ile yapılacak çalışmaların teşvik ve tercih edilmesine günümüz hizmet iş kolunun ihtiyacı olduğunu söylemek mümkündür. 
İş veren ve iş görenlerin beklentilerine cevap verecek olumlu çalışma iklimi ve işgücünü yükseltecek şekilde oluşturulacak duygu gösterimi kuralları öncesinde ise sadece başarı ve üretim beklentilerinden vaz geçerek çalışanları duygu yönetimi ve duygusal emek konularında daha fazla bilgilendiren, destekleyen ve onlara daha fazla değer veren uygulamalarla yer verilmelidir.

İşörenlerin örgütlerde duygularını nasıl gösterdikleri ve bu duyguların örgütsel amaçlar için nasıl kâr haline dönüştüğü hakkındaki duygusal emek çalışmaları işgörenlerin sosyal normlara ve iş yeri beklentilerine adapte olabilmek için duygularını kontrol edip yönetirlerken duygusal emek süreci sonunda ortaya çıktığ1 görülen bazı olumsuzluklar pozitif çalışma ortamı ve pozitif işgücünü yükseltmek suretiyle formüle edilecek duygusal davranış kuralları ve çalışana daha fazla destek veren ve değer yaratan insani uygulamalarla olumlu yönde değiştirilebilir.

Böylece, duygusal emek açısından önemli bir konu olan dikkat ve duygusal istikrarı ele alarak yeni bir model ortaya koyulabilir. Olumlu ve olumsuz duygu durumların hizmet sunumuna etkilerini deneysel olarak incelenebilir. Böylece derin duygusal emek gösterimi ve doğal duygusal emek davranışı gösterecek bazı kişilik özellikleri daha belirgin ve etkili bir şekilde tespit edilebilir. Yine, duygu ile ilgili bütün değişkenlerin ( duygusal emek, duygusal zeka, duygusal sermaye, duygu yönetimi ve duygusal düzenleme gibi) bir arada ele alınacağı araştırmaların da alanyazına büyü katkı sağlayacağı vurgulanması gereken diğer bir husustur.

Özetle, duygusal emek kavramı araştırmaları günümüz rekabet dünyasında küçük bir fark ve fayda oluşturabilmek için genelde olumlu duygular ve tebessüm ile hizmet etmenin kaçınılmazlığına dikkat çekmelidir. Bu nedenle, araştırmalarda işgörenin olumlu duygular sergilemek amaciyla duygusal emek davranışı gösterme gerekliliğinin onda ortaya çıkardığı olumsuzlukları ve bunların kaynaklarını ortadan kaldırmaya odaklanacak yaklaşımlara ihtiyaç vardır. Böylece olumlu duyguların doğallıkla ve derinlemesine gösterilebileceği hizmet sunumunu sonuç verecek duygu gösterim kuralları ve benzeri değişkenlere dönük araştırmalar gerçekleştirilmelidir. Çünkü hizmet sektöründeki kuvvetli rekabet anlayışlarından dolayı yoğun ve çok 
sayıda duygu gösterim kurallarının oluşturulması iş özerkliği, işe bağlılığı ve tükenmişlik olgusundan uzak bir performansı olumsuz etkilemektedir. Bu gibi sakıncaları giderebilecek sonuçlara ulaşan bilimsel çalışmalar duygusal emek davranışının daha etkili ve bilinçli bir şekilde yaygınlaşmasına neden olabilecektir.

\section{Kaynaklar}

Ahmed, S. (2004). The Cultural Politics of Emotion. Edinburg, Edinburg University, 224.

Ashforth, B. E. ve Humphrey, R. H. (1993). Emotional labor in service roles: the influence of 1dentity. Academy of Management Review. 18. No. 1,88-115.

Ashkanasy, N. ve Daus, C. (2001). Emotion in the workplace: the new challange for managers. Later published in Academy of Management Executive, 16(1), 76 - 86.

Barsade, S. ve Gibson D. (2007). Why does affect matter in organizations?. Academy of Management Perspectives, Febrary, 36-59.

Basım, H. N. ve Beğenirbaş, M. (2012). Çalışma yaşamında duygusal emek: bir ölçek uyarlama çalışması. Yönetim ve Ekonomi Dergisi, 19(1) 77-90.

Brotheridge, C. M., ve Lee, R. T. (2003). Development and validation of the Emotional Labor Scale. Journal of Occupational and Organizational Psychology, 76(3), 365-379.

Brotheridge, C.; Grandey, A. (2002). Emotional labor and burnout: comparing two perspectives on 'people work'. Journal of Vocational Behaviour, 60, 17-39.

Chi, N.-W. ve Grandey, A. A. (2016). Emotional labor predicts service performance depending on activation and inhibition regulatory fit. Journal of Management. 1-28.

Chu, Hei-Lin K. ve Murrmann, S. (2006). Development and validation of the hospitality emotional labor scale. Tourism Management. 27, 1181-1191.

Chu, Hei-Lin K. (2002). The effects of emotinal labor on employee work outcomes. Yayımlanmamış Doktora Tezi, Virginia: Polytechnic Institute and State University.

Çaldağ, M. Ali. (2010). Duygusal emek davranışlarının sağlık çalışanlarında iş sonuçlarına etkileri. Yayınlanmamış Yüksek Lisans Tezi. Konya: Selçuk Üniversitesi Sosyal Bilimler Enstitüsü.

Çukur, C. Ş. (2012). Duygusal düzenleme ve duygusal iş̧̧ilik konulu konferans; Ankara: Atı1 lı Üniversitesi. 
Deniz, E. Arslan, C. Özyeşil, Z. ve İzmirli, M. (2012). Öz-anlayış, yaşam doyumu, negatif ve pozitif duygu: Türk ve diğer ülke üniversite öğrencileri ile bir karşılaştırma. Mehmet Akif Ersoy Üniversitesi Eğitim Fakültesi Dergisi, 12 (23), 428-446.

Diefendorff, J. M. Richard, M. Erin M. C. ve Meredith H. (2006). Are emotional display rules formal job requirements? examination of employee and supervisor perceptions. Journal of Occupational and Organizational Psychology. 79. 273-298.

Diefendorff, J. M., Croyle, M. H., ve Gosserand, R. H. (2005). The dimensionality and antecedents of emotional labor strategies. Journal of Vocational Behavior, 66(2), 339-357.

Dursun, S. Bayram, N. ve Aytaç, S. (2011) Duygusal emeğin iş tatmini ve tükenme düzeyi üzerine etkisi. 17.Ulusal Ergonomi Kongresi. 14-16 Ekim, Eskişehir.

Erkuş, A. ve Günlü, E. (2008). Duygusal zekanın dönüşümcü liderlik üzerine etkileri. Dokuz Eylül Üniversitesi, İsletme Fakültesi Dergisi , 187-209.

Eroğlu, E. (2010). Örgütsel iletişimin işgörenlerin duygu gösterimlerinin yönetimine olan etkisi. Selçuk Illetişim. 6(3) 18-33.

Eroğlu, E. (2011). Iletişimci liderlik: yöneticilerin iletişimci biçimleri üzerine bir araştırma. Konya: Literatür yayınları.

Ezilmez, B. (2018). Duygusal emek gösterimlerinin bireysel ve örgütsel öncülleri ile sonuçları üzerine bir araştırma. Yayınlanmamış doktora tezi. Çanakkale: Çanakkale Onsekiz Mart Üniversitesi Sosyal Bilimler Enstitüsü.

Ezilmez, B. ve Eroğlu, U. (2017). Bursa ili sağlık çalışanlarında duygusal emek gösterimi. 5. örgütsel davranış kongresinde sunuldu. 1-3 Kasım, Antalya.

Gardner, W. L. Fischer, D. ve Hunt; J. G. (2009) Emotional Labor and Leadership: A threat to authenticity?. The Leadership Quarterly. 20, 466-482.

Goleman, D. (2007). Duygusal Zeka. İstanbul: Varlık Yayınları.

Grandey, A. A. (2015). Smiling for a wage: what emotional labor teaches us about emotion regulation. Psychological Inquiry. 26(1) 54-60.

Grandey, A. A. ve Gabriel, A. (2015). Emotional labor at a crossroads: where do we go from here?. Annual Review of Organizational Psychology and Organizational Behavior. 323-49.

Grandey, A. A. Rupp, D. ve Brice W. N. (2015). Emotional labor threatens decent work: a proposal to eradicate emotional display rules. Journal of Organizational Behaviour. $36,770-785$. 
Grandey, A. A.; Glenda M. F. Anna. S. M.; Karen J.; Lori A. S. (2005). Is "service with a smile" enough? authenticity of positive displays during service encounters. Organizational Behavior and Human Decision Processes, 96, 38-55.

Grandey, Alicia A. (2003). When "the show must go on": surface acting and deep acting as determinants of emotional exhaustion and peer-rated service delivery. Academy of Management Journal. 46(1) 86-96.

Grandey, A. A. (2000). Emotion regulation in the workplace: a new way to conceptualize emotional labor. Journal of Occupational Health Psychology. 5(1) 95-110.

Grandey, A. A. (1999). The effects of emotional labor; employee attitudes, stress and performance. Unpublished Doctoral dissertation, Colorado State University.

Güngör Delen, M. (2017). Emek sürecinde son nokta: duygusal emek ve tinsel emek. İstanbul: Türkmen Kitabevi.

Güngör Delen, M. (2009). Duygusal emek kavramı: süreci ve sonuçları. Kamu-İş. 11(1) 167183.

Hochschild, A. R. (1983). The managed heart: the commercialization of human feeling. Berkeley and Los Angeles: University of California Press.

Hochschild, A. R. (1979). Emotion work, feeling rules, and social structure. American Journal of Sociology, 85(3)551-575.

Humphrey, R. Pollack, H. Jeffrey M. ve Hawver, T. (2008). Leading with emotional labor. Journal of Managerial Psychology, 23(2) 151-168.

Isenbarger, L. ve Zembylas, M. (2006). The emotional labor of caring in teaching. Teaching and Teacher Education, 22, 120-134.

Kanfer, R. ve Kantrowitz, T.M. (2002). Emotion Regulation: Command and Control of Emotion in Work Life. In Lord RG, Klimoski R, Kanfer R (Eds.), Emotions in the workplace: Understanding the structure and role of emotions in organizational behavior (433-472). San Francisco, CA: Jossey-Bass.

Kart, E. (2011). Bir duygu yönetimi süreci olarak duygusal emeğin çalışanlar üzerindeki etkisi. Çalışma ve Toplum Ekonomi ve Hukuk Dergisi, 3, 215-230.

Kaya, U. Ç. ve Özhan, ÇK. (2012). Duygusal emek ve tükenmişlik ilişkisi: turist rehberleri üzerine bir araştırma. Çalışma İlişkileri Dergisi. 3(2) 109-130. 
Kervancı, Ü. F. (2008). Büro çalışanlarının duygu yönetimi yeterlilik düzeylerinin geliştirilmesinde duygu yönetimi ĕgitimi programının etkisi. Yayımlanmamış Yüksek Lisans Tezi. Ankara: Gazi Üniversitesi Eğitim Bilimleri Enstitüsü.

Köksel, L. (2009). İ̧̧ yaşamında duygusal emek ve ampirik bir çalışma. Yayınlanmamış Yüksek lisans tezi, Manisa: Celal Bayar Üniversitesi Sosyal bilimler Enstitüsü.

Kruml, S. M.; Geddes, D. (2000). Exploring the dimensions of emotional labor: the heart of hochschild's work. Management Communication Quarterly, 14(1) 8-49.

Leavitt, J. (1996). Meaning and Feeling in the Anthropology of Emotions. American Ethnologist, 514-519.

Massumi, B. (2002). Parables for the virtual: movement, affect, sensation. London: Duke University Press.

McGuire, Tammy. (2010). From emotions to spirituality: "spiritual labor" as the commodification, codification, and regulation of organizational members' spirituality. Management Communication Quarterly. 24(1) 74-103.

Morris, J. A. ve Feldman, D. C. (1996). The dimensions, antecedents and consequences of emotional labor. Academy ot Management Review. 21(4) 986-1010.

Newman, M. A. Guy, M. Mastracci, M. E. ve Sharon H. (2009). Beyond cognition: affective leadership and emotional labor. Public Administration Review. January -February.

Oral, L. Köse, S. (2011). Hekimlerin duygusal emek kullanımı ile iş doyumu ve tükenmişlik düzeyleri arasındaki ilişkiler üzerine bir araştırma. Süleyman Demirel Üniversitesi Íktisadi ve İdari Bilimler Fakültesi Dergisi, 16(2) 463-492.

Öz, E. Ü. (2007). Duygusal emek davranışlarının çalışanların iş sonuçlarına etkisi. İstanbul: Beta.

Pugh D. S. (2001). Service with a smile: emotional contagion in the service encounter. The Academy of Management Journal. 44(5),1018-1027.

Rafaelli, A. Sutton, R. (1989). The expression of emotion in organizational life. In B.M. Staw, L.L. Cummings (Ed.). Research on organizational behavior. Greenwish, CT: JAI Press.

Seçer, Ş. H. (2005); Çalışma yaşamında duygular ve duygusal emek: sosyoloji, psikoloji ve örgüt teorisi açısından bir değerlendirme. Sosyal Siyaset Konferansları Dergisi, Prof. Dr. Nevzat Yalçıntaş’a Armağan Özel Sayısı. 0. 50. 813-834. 
Steinberg, R. J. ve Figart, D. M. (1999). Emotional Demands at Work: A Job Content Analysis. Annals of the American Academy of Political and Social Science. 561. Emotional Labor in the Service Economy (January). 177-19.

Sutton, R. E., ve Wheatley, K. F. (2003). Teachers' emotions and teaching: a review of the literature and directions for future research. Educational Psychology Review, 15(4), 327-358.

Şengül, A. (2009). Hizmet işletmelerinde yüksek ilişik kalitesine ulaşılmasında sınır birim işgörenlerinin duygu işçisi olarak değerlendirilmesi. Ege Akademik Bakış. 9(4) 1193-1211.

Töremen, F. ve Çankaya, İ. (2008). Yönetimde etkili bir yaklaşım: duygu yönetimi. Kuramsal Eğitimbilim. 1(1) 33-47.

Tsai, W. C. (2001). Determinants and consequences of employee displayed positive emotions. Journal of Management. 27, 497-512.

Türkay, O. ve Ünal, A. (2010). Duygusal Emek Davranışının Yönetilmesi: Sakarya Otelleri Örneği; IX. Geleneksel Turizm paneli, Nisan. Sakarya.

Türkay, O. Ünal, A. ve Taşar, O. (2011). Motivasyonel ve yapısal etkenler altında duygusal emeğin işe bağlılığa etkisi; ZKÜ Sosyal Bilimler Dergisi, 7, 14.

Weiss, H. ve Cropanzano, R. (1996). Effective events theory: a theoretical discussions of the structure, causes and consequences of affective experiences at work. in Barry M. Staw and Larry.L. Cummings (Ed.) Research in Organizational Behaviour, 18, 17-19.

Wharton, A. S. ve Erickson, ve R. J. (1993). Managing emotions on the job and at home: understanding the consequences of muliple emotional roles. Academy of Management Review, 18(3) 457-486.

Wharton, A. S. (1999). The psychosocial consequences of emotional labor, The Annals Of The American Academy of Political And Social Science. 561: 158--Annals, Aapss. January.

Wouters, C. (1989). The sociology of emotions and flight attendants: hochschild's managed heart. Theory, Culture and Society, 6, 95-123.

Yalçın, A. (2010). Emotional labour: dispositional antecedents and the role of affective events. A thesis submitted to the graduate school of social sciences of METU, September.

Zapf, D. Vogt, C. Seifert, C. Mertini, H. ve Isic, A. (1999). Emotion work as a source of stress: the concept and development of an instrument. European Journal of Work and Organizational Psychology, 8, 371-400. 